\title{
EDITORIAL: KOERS VOLUME 80, NO 1, 2015
}

Author:

Prof Annette Combrink

\section{Affiliation:}

Research associate, Department Languages and Literature, North West University.

\section{Correspondence to:}

A Combrink

\section{Email:}

anette.combrink@nwu.ac.za

\section{Postal address:}

PO Box 19124, Noordbrug 2522

\section{Dates:}

Accepted: 01 Jun. 2015 Published: 01 Sep. 2015

\section{How to cite this article:}

Combrink, A., 'Editorial: Koers, Volume 80, No 1, 2015', KOERS - Bulletin for Christian Scholarship 80(1), Art. \#2205, 12 pages. http:// dx.doi.org/10.19108/ koers.80.1.2202

\section{Copyright:}

(c) 2015. The Author(s)

Published under the

Creative Commons

Atribution License.
As indicated in the first issue of Koers in 2014, there has been a fairly radical shift at the journal. In this, the eightieth year of its existence, it has been fairly hard going to keep "koers" and stay on track.

The former editor, Helena Hoogstad, has in the meantime resigned as editor, as her life has changed, what with her studies in Canada and her husband obtaining good employment in Canada. I have therefore been asked to take over as editor and will keep you informed about developments.

Apart from changing horses in midstream, as it were, the Koers Society had also last year decided to change from one online service provider to another, and this has also not been without a few hiccups. However, we are pleased to announce that the first issue will be online in the first week of September, and the next one towards the end of September. The full complement of the year will be published before the end of the year. I am pleased to be able to say that we have enough material coming in to keep the journal running and keeping readers informed about what is happening in the field of scholarship informed by world view. The website has been redesigned, and you are invited to visit it (www.koersjournal.org.za).

The articles in this issue come from some authors whom we have long known, as well as some contributions from new contributors. It is always gratifying to find new authors working in the field and keeping the interest in this form of scholarship alive and vibrant.

Because this is such a significant birthday year, we will be publishing one or more commemorative issues next year. More information about this will be provided in the next issue, so that scholars can begin to generate their ideas and participate in the celebration of such a landmark in the existence of a journal - officially one of the very oldest journals in the country, and one that has been published continuously, sometimes under very serious constraints, financial and otherwise, for 80 years.

Annette Combrink Editor-in-Chief, Koers 